\title{
PENGARUH MODEL PEMBELAJARAN BEYOND CENTERS AND CIRCLE TIMES (BCCT) DAN KEMANDIRIAN TERHADAP KREATIVITAS
}

\author{
ADIANTI RUQOYAH \\ PAUD PPs Universitas Negeri Jakarta \\ Jl. Rawamangun Muka, Jakarta Timur. \\ Email: Adianti.ruquyah@gmail.com
}

\begin{abstract}
This study aims to identify and analyze the influence of the learning model beyond centers and circle times (BCCT) and the child's independence against group B TK creativity Amanah West Jakarta. A sample of 34 children using Random Sampling technique Stratifeid. The instrument uses a questionnaire of independence and creativity test tool. Testing is done with the correlation validity and reliability testing point biserial Kuder- Richardson reliability coefficients 20. In this study hypothesis test conducted with hotelling $t$ multivariate analysis, independent $t$ test and chi square analysis. The results showed: 1) there are differences in child outcomes that have low creativity among groups and non BCCT bct (T-hitung (36.6)> C2 (11.83)). 2) there are differences in the results of children who have high creativity among groups and non BCCT BCCT (T2hitung (36.6)> C2 (11:45)). 3) There is an interaction effect BCCT learning model and the independence of thecreativity of children (p-value 0.013). 4) There are differences in the results of children who have low self-reliance among groups and non BCCT BCCT (t2hitung (95.51)> c2 $(12: 33))$. 5) there are differences in the results of children who have high self-reliance among groups and non BCCT BCCT (t2hitung (82.47)> c2 (12:33).
\end{abstract}

Keywords: beyond center and circle time, independence, creativity.

Abstrak: Penelitian ini bertujuan untuk mengetahui dan menganalisis pengaruh model pembelajaran beyond centers and circle times dan kemandirian anak terhadap kreativitas kelompok B TK Amanah Jakarta Barat. Sampel sebanyak 34 anak dengan menggunakan teknik Stratifeid Sampling Random. Instrumen menggunakan kuesioner kemandirian dan alat tes kreativitas. Pengujian validitas dilakukan dengan korelasi point biserial dan pengujian reliabilitas koefisien Reliabilitas Kuder- Richardson 20. Dalam penelitian ini uji hipotesis dilakukan dengan analisis multivariate $\mathrm{t}$ hotelling, uji $\mathrm{t}$ independen dan analisis chi square. Hasil penelitian menunjukkan: 1) terdapat perbedaan hasil anak yang memiliki kreativitas rendah antara kelompok BCCT dan non BCCT $\left(\mathrm{T}^{2}{ }_{\text {hitung }}(36.6)>\mathrm{C}^{2}(11.83)\right)$. 2) terdapat perbedaan hasil anak yang memiliki kreativitas tinggi antara kelompok BCCT dan non BCCT $\left(\mathrm{T}^{2}{ }_{\text {hitung }}(36.6)>\mathrm{C}^{2}(11.45)\right)$. 3) Terdapat pengaruh interaksi model pembelajaran bcct dan kemandirian terhadap kreativitas anak (p-value 0,013). 4) Terdapat perbedaan hasil anak yang memiliki kemandirian rendah antara kelompok BCCT dan non BCCT $\left(\mathrm{t}^{2}{ }_{\text {hitung }}(95.51)>\mathrm{c}^{2}(12.33)\right)$. 5) terdapat perbedaan hasil anak yang memiliki kemandirian tinggi antara kelompok BCCT dan non BCCT $\left(\mathrm{t}^{2}{ }_{\text {hitung }}(82.47)>\mathrm{c}^{2}(12.33)\right)$.

Kata kunci: beyond center and circle time, kemandirian, kreativitas. 


\begin{abstract}
Sektor pendidikan yang paling mendasar dalam pembentukan pribadi sumber daya manusia yaitu melalui program Pendidikan Anak Usia Dini (PAUD). Menurut UndangUndang Sisdiknas pasal 28, tentang PAUD terdiri dari tiga jalur pendidikan, yaitu jalur formal yang meliputi Taman Kanak-Kanak (TK), Raudhatul Atfhal (RA) atau bentuk lain yang sederajat, jalur Non-formal meliputi Kelompok Bermain (KB) Taman Penitipan Anak (TPA), atau bentuk lain yang sederajat.
\end{abstract}

Dalam meningkatkan mutu pendidikan anak usia dini pemerintah menerapkan salah satu program yang dinamakan program pendidikan berkarakter. Program pendidikan berkarakter menerapkan beberapa aspek penanaman pengetahuan, kecintaan dan penanaman perilaku kebaikan menjadi sebuah pola/kebiasaan.

$\begin{array}{rlr}\text { Salah } & \text { satu aspek yang } \\ \text { ditekankan } & \text { dalam program }\end{array}$

pendiidikan berkarakter adalah kreativitas. Menurut Rachmawati dan Kurniati (2010: 6) dalam penelitian yang dilakukan oleh Jellen dan Urban pada tahun 1987 Tingkat kreativitas anak Indonesia tergolong rendah. Penelitian tersebut menunjukkan bahwa Indonesia menempati posisi terendah dibandingkan 8 negara lainnya antara lain, Filipina, Amerika Serikat, Inggris, Jerman, India, RRC, Kamerun, dan Zulu. Meskipun kreativitas anak Indonesia tergolong rendah namun, dalam pembelajaran pada tingkat Pendidikan Anak Usia Dini belum sepenuhnya mengembangkan kreativitas anak. Pembelajaran lebih menekankan pada perkembangan kognitif yang menekankan pada kemampuan anak menulis, berhitung dan membaca. Sistim penilaian yang diberikan guru kepada anak menekankan hasil dari pada proses.

Dalam mengembangkan kreativitas anak diperlukan pula pengembangan kemandirian 
pada anak. Sehingga anak berani untuk mengembangkan potensi kreatif dalam dirinya. Hal tersebut sejalan dengan Harjaningrum (2007:17) yang mengatakan bahwa kreativitas berkaitan dengan kemandirian dan keingintahuan seseorang.

Saat ini model pembelajaran pendidikan anak usia dini masih didominasi oleh pengajaran berpusat pada guru. Untuk meningkatkan efisiensi pembelajaran, pemerintah mengadopsi salah satu model pembelajaran yaitu model pembelajaran BCCT (Beyond Centers and Circle Time) atau model pembelajaran sentra dan lingkaran.

Dalam penelitian yang dilakukan oleh Sukiman terdapat hasil bahwa model pembelajaran BCCT dapat meningkatkan kreativitas anak.

\section{Berdasarkan pemikiran} diatas, peneliti termotivasi untuk mengacu pada model pembelajaran BCCT dan kemandirian dalam meningkatkan kreativitas anak usia dini. Penelitian ini akan dilakukan di TK Amanah Jakarta barat.

\section{Kreativitas}

Kreativitas merupakan menciptakan suatu hal yang baru dan unik baik itu tulisan maupun lisan dan mendatangkan keuntungan untuk diri sendiri maupun orang lain. Taylor dalam Munandar mengatakan kreativitas merupakan kemampuan untuk melihat atau memikirkan hal-hal yang luar biasa, yang tidak lazim, memadukan informasi yang tampaknya tidak berhubungan dan mencetuskan solusi-solusi baru dan gagasan-gasan baru yang mencerminkan kelancaran (fluency), keluwesan (flexibility), dan orisinalitas dalam berpikir. Munandar mengemukakan ciri-ciri dari perilaku kreatif antara lain:

a. Kelancaran berpikir (fluency of thinking), yaitu kemampuan untuk menghasilkan banyak ide yang keluar dari pemikiran seseorang secara relevan. 
Dalam kelancaran berpikir, yang baru, baik berupa gagasan yang ditekankan adalah maupun karya nyata, baik dalam kuantitas, dan bukan kualitas. bentuk karya baru maupun

b. Keluwesan berpikir (flexibility), yaitu kemampuan untuk memproduksi sejumlah gagasan yang seragam, dapat melihat suatu masalah dari sudut pandang yang berbedabeda, mencari alternatif atau arah yang berbeda-beda, serta mampu menggunakan bermacam-macam pendekatan atau cara pemikiran.

c. Elaborasi (elaboration), yaitu kemampuan dalam mengembangkan, menambah, memperkaya suatu gagasan dan menambahkan atau memperinci detail-detail dari suatu objek.

d. Originalitas (originality), yaitu kemampuan untuk memberikan jawaban atau gagasan yang lain dari yang lain, yang jarang diberikan kebanyakan orang.

Berdasarkan deskripsi teori yang telah diungkapkan, maka disimpulkan bahwa kerativitas adalah kemampuan yang dimiliki seseorang untuk menciptakan sesuatu 84 kombinasi dengan hal-hal yang sudah ada, dengan menekankan kemampuan untuk mengkombinasikan, memecahkan atau menjawab masalah. Kreativitas diukur dengan indikator-indikator sebagai berikut: 1) kelancaran berpikir, 2) keluwesan berpikir, 3) elaborasi 4) originalitas.

\section{Model Pembelajaran BCCT}

Salah satu model pembelajaran yang mengedepankan minat anak adalah model pembelajaran BCCT (Beyond Centers and Circle Time.) BCCT (Beyond Centers and Circle Times) d =icetuskan oleh Pamela C Phelps, Ph.D dan dikembangkan oleh Creative Center for Childhood Research (CCCRT) di Florida, Amerika Serikat dimana Pamela langsung bertindak sebagai direkturnya. BCCT (Beyond Centers and Circle Times) dikembangkan oleh Pamela C Phelps, Ph.D setelah meneliti banyak negara termasuk Indonesia dan memiliki creative 
preschool sebagai model sekolah inklusif, Pamela melakukan penelitian selama 30 tahun. Sujiono (2009:216) model pembelajaran BCCT merupakan suatu metode atau pendekatan dalam penyelenggaraan pendidikan Anak Usia Dini dan merupakan perpaduan antara teori dan pengalaman praktik. pembelajaran BCCT merangsang anak untuk aktif, kreatif dan terus berfikir dengan menggali pengalamannya sendiri. Nuryani (2012:11) menerangkan bahwa BCCT merupakan suatu konsep pembelajaran yang difokuskan pengalaman dunia nyata hadir di dalam kelas dan mendorong anak didik untuk membuat hubungan antara pengalaman, pengetahuan dan pemahaman kehidupan sehari-hari, sehingga anak menemukan pengalamannya secara sendiri tanpa pengaruh langsung dari guru.

\section{Kemandirian}

Dalam mengembangkan kreativitas anak diperlukan pula pengembangan kemandirian pada anak. Sehingga anak berani untuk mengembangkan potensi kreatif dalam dirinya. Hal tersebut Sejalan dengan pernyataan Rachmawati dan Kurniati (2010:13) yang mengatakan bahwa salah satu karakteristik Anak yang kreatif adalah mempunyai kemandirian. Erickson dalam Desmita (2012:185) menyatakan kemandirian atau otonomi adalah kemampuan untuk melepaskan diri dari orangtua dengan maksud untuk menemukan dirinya melalui proses mencari identitas ego, yakni perkembangan menuju diri yang berdiri sendiri. Menurut Chaplin (1999:48) Kemandirian seseorang ditunjukkan melalui keyakinannya yang digambarkan dalam rasa percaya diri atas kemampuan dalam menyelesaikan sesuatu. Menurut Marshall kemadirian anak ditunjukkan dengan memakai baju sendiri, makan secara rutin, dapat ketoilet, dapat menggunakan peralatan makan sendiri

Berdasarkan deskripsi teori yang telah diungkapkan, maka kemandirian diartikan sebagai kebebasan dan kemampuan anak dalam mengatur perilakunya tanpa adanya kontrol serta pengaruh dari orang lain. Kemandirian diukur 
dengan indikator-indikator yaitu: 1) inisiatif, 2) memiliki tanggungjawab, 3) kontrol diri, 4) percaya diri, 5) memiliki kemampuan mengatasi masalah, 6) tidak bergantung kepada orang lain.

Berdasarkan penjelasan diatas peneliti terarah untuk meneliti apakah adanya pengaruh model pembelajaran BCCT dan kemandirian terhadap kreativitas. Dimana tujuan utama penelitian ini ingin mengetahui

1. Perbedaan hasil anak yang mempunyai kreativitas rendah yang diajar menggunakan model pembelajaran Beyond Centers And Circles Time (BCCT) dan non BCCT.

2. Perbedaan hasil anak yang mempunyai kreativitas Tinggi yang diajar menggunakan model pembelajaran Beyond Centers And Circles Time (BCCT) dan non BCCT.

3. Pengaruh interaksi model pembelajaran Beyond Centers And Circles Time (BCCT) dan kemandirian terhadap kreativitas anak.
4. Perbedaan hasil anak yang memiliki kemandirian belajar tinggi diajar menggunakan model pembelajaran Beyond Centers And Circles Time (BCCT) dan non BCCT.

5. Perbedaan hasil anak yang memiliki kemandirian belajar rendah diajar menggunakan model pembelajaran Beyond Centers And Circles Time (BCCT) dan non BCCT.

\section{Metodologi Penelitian}

Metode yang digunakan dalam penelitian ini merupakan metode kuantitatif Ex post facto. dengan Disain faktorial $2 \times 2$. Disain ini dipilih karena sampel penelitian dibagi dalam dua kelompok yang diajar dengan model BCCT dan Non BCCT Yaitu TK Amanah yang menerapkan model pembelajaran Beyond Centers And Circles Time (BCCT) dan TK Kertapawitan yang tidak menerapkan model pembelajaran Non BCCT. Penelitian ini dilakukan selama 11 bulan yang dimulai dari bulan November 2014 sampai dengan Oktober 2015. Pengambilan sampel dalam enelitian 
ini menggunakan multi strage random sampling.

\section{Adapun langkah-langkah}

dalam pemilihan sampel penelitian sebagai berikut: 1) menentukan daerah yang terpilih berdasarkan kecamatan di jakarta barat 2) setelah itu menentukan sekolah yang akan dijadikan Penelitian dengan memperhatikan model pembelajaran yang digunakan serta tingkat akreditasi 3) melakukan pemilihan pengukuran kemandirian pada masing-masing kelas, dengan menggunakan instrumen kemandirian yang telah disusun oleh peneliti. Dalam pengembangan imstrumen terlebih dulu dilakukan uji coba instrument dengan pengujian validitas isi dan validita butir, serta reliable dengan sampel yang berbeda. Setelah valid dan reliabel. Instrument digunakan untuk mengukur variable. Terdiri dari dua instrument, kuesioner kemandirian dan alat tes kreativitas.

Setelah data terkumpul, maka dilakukan tabulasi data dengan memberikan skor dari setiap jawaban yang diberikan responden atau subyek penelitian untuk dilakukan pengolahan data. Dalam penelitian ini analisis data meliputi statistika deskriptik, uji normalitas data (persyaratan analisis) dan statistika inferensial untuk pengujian hipotesis. Analisis deskripsi dilakukan untuk setiap variabel penelitian yang meliputi: perhitungan mean, standar deviasi, skor minimum dan skor maksimum. Sesudah analisis deskriptif dilanjutkan dengan analisis inferensial yang digunakan untuk menguji hipotesis penelitian. Dalam penelitian ini uji hipotesis dilakukan dengan analisis multivariate $t$ hotelling guna melihat perbedaan 2 variabel multivariate (memiliki beberapa dimensi didalamnya) yang selanjutnya dilakukan uji $t$ independen guna melihat dimensi mana yang terdapat perbedaan, dan selanjutnya untuk melihat interaksi antara kemandirian dan kreativitas berdasarkan tinggi rendah dan kelompok BCCT dan Non BCCT digunakan analisis chi square. Sebelum dilakukan pengujian hipotesis, dilakukan terlebih dahulu uji persyaratan yaitu uji normalitas. Uji normalitas dilakukan untuk mengetahui apakah data berasal dari 
populasi yang berdistribusi normal. Dalam pengujian ini dilakukan dengan uji Kolmogorov Smirnov yang didasarkan pada koefisien KS hitung dan P-value. Pengujian

\section{Hasil Dan Pembahasan}

Perbedaan Hasil Anak yang mempunyai Kreativitas Rendah antara Kelompok BCCT dan Non BCCT

Berdasarkan perhitungan $t$ hotteling $\mathrm{T}^{2}$ hitung $(36.6)>\mathrm{C}^{2}(11.83)$ maka Ho ditolak, atau dapat disimpulkan bahwa Terdapat perbedaan Hasil Anak yang memiliki Kreativitas Rendah antara kelompok BCCT dan Non BCCT. Untuk mengetahui masing-masing dimensi mana (Kelancaran, Keluwesan, Elaborasi, dan Original) yang berbeda antara Kelompok BCCT dan Non BCCT maka digunakan Analisis lanjutan yaitu uji t independent.

Berdasarkan analisis lanjutan mengenai Kreativitas anak yang Rendah antara BCCT dan NON BCCT, dapat diketahui bahwa ratarata Kelancaran pada kelompok non BCCT adalah 5.92 selanjutnya untuk normalitas dilakukan secara univariat. Dalam analisis data penelitian ini menggunakan program komputer SPSS 15 dan excel.

dimensi memiliki Keluwesan sebesar 1.13, lalu pada dimensi Elaborasi sebesar 1.13, dan pada dimensi Original sebesar 4.63.

Sedangkan rata-rata Kelancaran pada kelompok BCCT adalah 12.73 selanjutnya untuk dimensi memiliki Keluwesan sebesar 3.36, lalu pada dimensi Elaborasi sebesar 3.27, dan pada dimensi Original sebesar 7.27.

Berdasarkan hasil pengujian kesamaan rata-rata pada masingmasing dimensi, terlihat bahwa terdapat seluruh dimensi yang terdapat perbedaan pada Kreativitas rendah antara kelompok BCCT dan Non BCCT, yaitu pada Dimensi memiliki kelancaran, keluwesan, elaborasi, dan original. hal ini dikarenakan pada seluruh dimensi tersebut memiliki nilai $\mathrm{t}$ hitung $\geq \mathrm{t}$ tabel yaitu $\mathrm{t}$ hitung untuk memiliki inisiatif sebesar 2,034, dengan demikian dapat disimpulkan terdapat 
perbedaan yang signifikan pada Kreativitas rendah anak antara kelompok BCCT dan Non BCCT pada seluruh Dimensinya.

Dalam penelitian ini ditemukan bahwa terdapat perbedaan yang signifikan antara kreativitas anak pada kelompok rendah yang diajar dengan model pembelajaran BCCT dan Non BCCT, yaitu anak dengan model pembelajaran non BCCT lebih rendah dibanding dengan BCCT. Dimana dimensi kelancaran memiliki tingkat beda yang tinggi dan dalam setiap dimensi ditemukan perbedaan yang signifikan.

Perbedaan ini juga dapat diakibatkan oleh tingkat SDM guru atau pengajar, dimana berperan penting pada anak dalam memberikan sarana untuk mestimulasi kreativitas anak. Dengan SDM yang tidak mendukung atau rendah anak belajar lebih cepat bosan karena tidak adanya ide yang menarik dari pengajar.
Perbedaan Hasil Anak yang mempunyai Kreativitas Tinggi Antara Kelompok BCCT dan Non BCCT

hasil perhitungan hipotesis diatas nilai $\mathrm{T}^{2}{ }_{\text {hitung }}(36.6)>\mathrm{C}^{2}$ (11.45) maka Ho ditolak, atau dapat disimpulkan bahwa Terdapat perbedaan Hasil Anak yang memiliki Kreativitas Tinggi antara kelompok BCCT dan Non BCCT. Untuk mengetahui masing-masing dimensi mana (Kelancaran, Keluwesan, Elaborasi, dan Original) yang berbeda antara Kelompok BCCT dan Non BCCT maka digunakan Analisis lanjutan yaitu uji t independent.

Berdasarkan hasil analisis lanjutan penelitian mengenai Kreativitas anak yang Tinggi antara BCCT dan NON BCCT, dapat diketahui bahwa rata-rata Kelancaran pada kelompok non BCCT adalah 19,50 selanjutnya untuk dimensi memiliki Keluwesan sebesar 3,50, lalu pada dimensi Elaborasi sebesar 2,70, dan pada dimensi Original sebesar 7,40. 
Sedangkan memiliki kelancaran, keluwesan, dan Kelancaran pada kelompok BCCT elaborasi, sedangkan tidak demikian adalah 22,91 selanjutnya untuk pada original, hal ini dikarenakan dimensi memiliki Keluwesan sebesar pada seluruh dimensi tersebut 4,30, lalu pada dimensi Elaborasi memiliki nilai $\mathrm{t}$ hitung $\geq \mathrm{t}$ tabel yaitu sebesar 4,39, dan pada dimensi Original sebesar 8,13.

Berdasarkan hasil pengujian kesamaan rata-rata pada masingmasing dimensi, terlihat bahwa terdapat 3 (tiga) dimensi yang terdapat perbedaan pada Kreativitas tinggi antara kelompok BCCT dan Non BCCT, yaitu pada Dimensi

Pada masing masing dimensinya ditemukan perbedaan pada dimensi kelancaran, keluwesan, elaborasi dan tidak terdapat perbedaan pada dimensi originalitas.

Secara teori, tidak terdapat perbedaan pada dimensi originalitas dapat diakibatkan karena adanya t hitung untuk memiliki inisiatif sebesar 2,034, sedangkan pada dimensi original didapatkan nilai $\mathrm{t}$ hitung hanya 1,993. Dengan demikian dapat disimpulkan terdapat perbedaan yang signifikan pada Kreativitas tinggi anak antara kelompok BCCT dan Non BCCT

yang memumpuni anak sehingga walau sekolah tidak menggunakan metode BCCT, dirumah dia mendapatkan stimulus yang baik atau pengajaran yang baik dari orang tua sehingga perkembangan kreativitasnya tetap berkembang dengan baik. 
Uji interaksi Kemandirian Anak terhadap Kreativitas pada Kelompok

BCCT dan Non BCCT

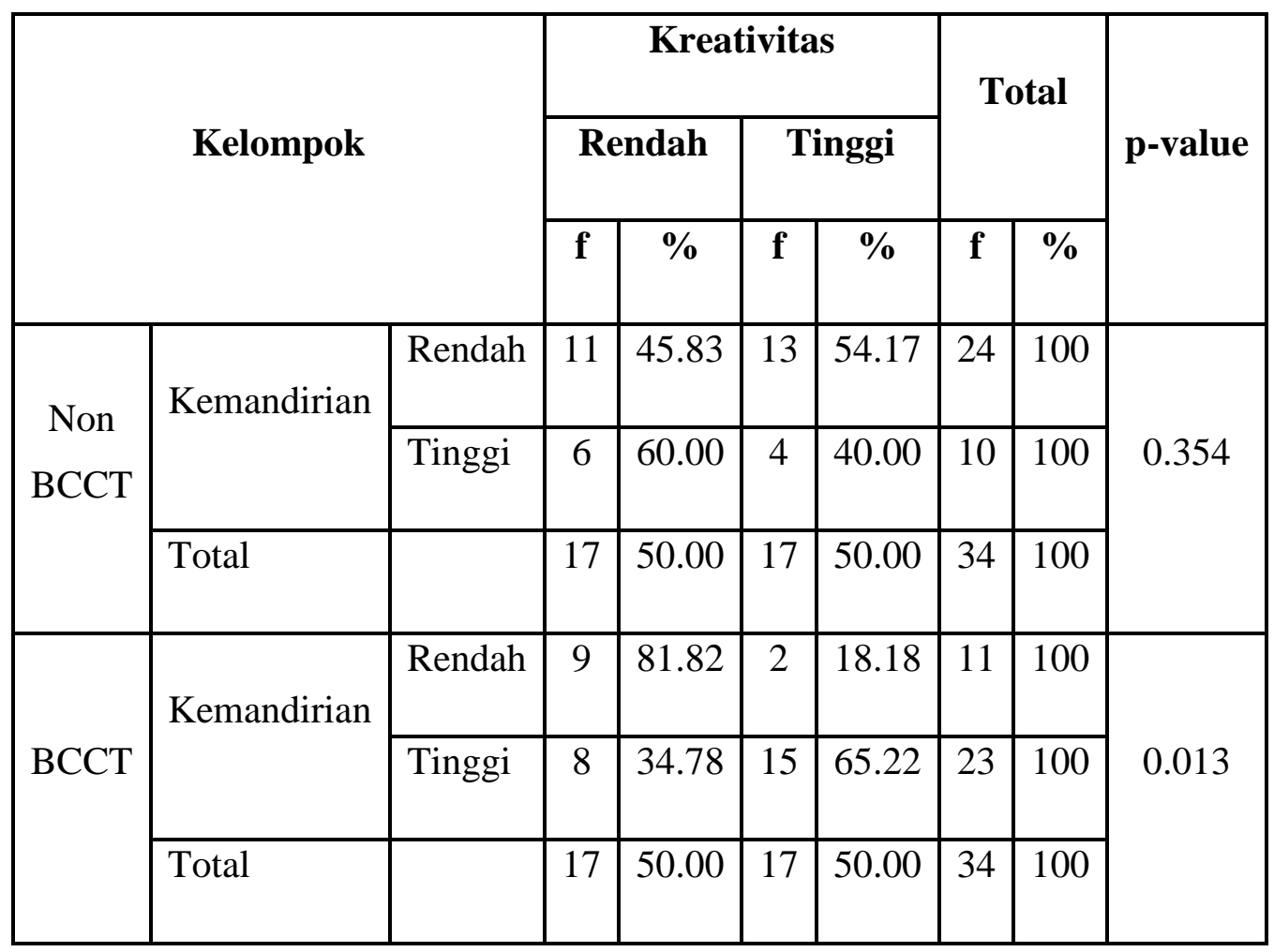

Berdasarkan tabel di atas, dapat dilihat bahwa dari 24 responden kelompok Non BCCT dengan kemandirian rendah sebanyak $\quad 45.83 \% \quad$ memiliki kreativitas yang rendah pula dan $54.17 \%$ lainnya dengan kreativitas yang tinggi. Sedangkan dari 10 responden kelompok Non BCCT dengan kemandirian tinggi sebanyak $60 \%$ memiliki kreativitas yang rendah dan $40 \%$ lainnya dengan kreativitas yang tinggi. Dari 11 responden kelompok BCCT dengan kemandirian rendah sebanyak $81.82 \%$ memiliki kreativitas yang rendah pula dan $18.18 \%$ lainnya dengan kreativitas yang tinggi. Sedangkan dari 23 responden kelompok BCCT dengan kemandirian tinggi sebanyak 35\% memiliki kreativitas yang rendah dan $65 \%$ lainnya dengan kreativitas yang tinggi. 
Hasil uji chi kuadrat untuk kelompok Non BCCT didapat pvalue 0,354 yang bernilai lebih dari 0,05 sehingga Ho diterima. Hal ini menunjukkan bahwa pada kelompok Non BCCT tidak terdapat interaksi kemandirian pada kreativitas anak. Berbeda dengan kelompok BCCT, didapat p-value 0,013 yang bernilai kurang dari 0,05 sehingga Ho ditolak. Hal ini menunjukkan bahwa pada kelompok BCCT terdapat interaksi kemandirian pada kreativitas anak. Kemandirian anak yang rendah cenderung memiliki kreativitas rendah, begitu juga dengan kemandirian yang tinggi akan memiliki kreativitas yang tinggi pula.

Hasil pengujian hipotesis ketiga menunjukkan tidak adanya perbedan antara kreativitas dan kemandirian anak yang berada dikolompok BCCT. Hal tersebut mnegindikasikan bahawa metode Non BCCT tidak dapat menstimulus dengan baik anak dengan kemandirian tinggi untuk meningkatkan kreativitasnya dengan baik. Hal tersebut dikarenakan pengajaran lebih berpusat pada guru sehingga tidak ada kebebasan pada anak dalam mengeksplorasi kemampuannya dan menjelajahi berbagai pengalaman.

\section{Perbedaan Hasil Anak yang} mempunyai Kemandirian Rendah antara Kelompok BCCT dan Non BCCT

Berdasarkan perhitungan nilai $\mathrm{T}_{\text {hitung }}^{2}(95.51)>\mathrm{C}^{2}$ (12.33) maka Ho ditolak, atau dapat disimpulkan bahwa Terdapat perbedaan Hasil Anak yang memiliki Kemandirian Rendah antara kelompok BCCT dan Non BCCT. Untuk mengetahui masing-masing dimensi mana (Inisiatif, Tanggung Jawab, Kontrol diri, Percaya Diri, Kemampuan Mengatasi Masalah dan Tidak Bergantung Orang Lain ) yang berbeda antara Kelompok BCCT dan Non BCCT maka digunakan Analisis lanjutan yaitu uji t independent.

Berdasarkan hasil penelitian lanjutan mengenai Kemandirian anak yang Rendah antara BCCT dan NON BCCT, dapat diketahui bahwa ratarata inisiatif pada kelompok non BCCT adalah 1.59 selanjutnya untuk 
dimensi memiliki tanggung jawab sebesar 1.71, lalu pada dimensi kontrol diri sebesar 1.59, pada dimensi Percaya diri sebesar 1.76, pada dimensi Memiliki kemampuan mengatasi masalah sebesar 1.24 dan dimensi Tidak bergantung pada orang lain sebesar 0.94 .

Sedangkan pada kelompok BCCT diketahui bahwa rata-rata inisiatif sebesar 2.00, selanjutnya untuk dimensi memiliki tanggung jawab sebesar 2.76, lalu pada dimensi kontrol diri sebesar 2.12, pada dimensi Percaya diri sebesar 2.59, pada dimensi Memiliki kemampuan mengatasi masalah sebesar 1.35 dan dimensi Tidak bergantung pada orang lain sebesar 2.35 .

Terlihat bahwa pada kemandirian anak yang rendah untuk kelompok Non BCCT dimensi paling tinggi berdasarkan rata-ratanya adalah pada Dimensi Percaya Diri, sedangkan pada kelompok BCCT adalah Dimensi Memiliki Tanggung Jawab.
Berdasarkan hasil pengujian kesamaan rata-rata pada masingmasing dimensi, terlihat bahwa hanya ada tiga dimensi yang terdapat perbedaan pada kemandirian rendah antara kelompok BCCT dan Non BCCT, yaitu pada Dimensi memiliki tanggung jawab serta percaya diri dan Tidak Bergantung Pada orang lain. Hal ini dikarenakan pada dimensi tersebut memiliki nilai $\mathrm{t}$ hitung $\geq \mathrm{t}$ tabel yaitu $\mathrm{t}$ hitung untuk memiliki tanggung jawab sebesar 3.387 dan percaya diri sebesar 2,432 serta Tidak Bergantung pada Orang Lain sebesar 5.367, terlihat juga untuk probability sig. 2 tailed masing-masing yaitu $0.002,0.021$ dan 0.000 yang lebih kecil dari taraf signifikansi 0.05 yang berarti Ho ditolak, dengan demikian dapat disimpulkan terdapat perbedaan yang signifikan pada kemandirian rendah anak antara kelompok BCCT dan Non BCCT pada dimensi Memiliki Tanggung Jawab, Percaya diri, dan Tidak bergantung pada orang lain, sedangkan pada dimensi Inisiatif, Kontrol diri, kemampuan mengatasi masalah tidak terdapat perbedaan yang signifikan. 
Pada kelompok BCCT dimensi tanggung jawab menjadi dominan, hal ini karenakan salah satu pembiasaan metode BCCT adalah membereskan mainan saat pijakan setelah bermain sehingga hal tersebut sudah terinternalisasi pada anak dan menjadi pembiasaan untuk meningkatkan tanggungjawab pada anak. Pada dimensi inisiatif, kontrol diri, dan kemampuan mengatasi masalah tidak terlihat adanya perbedaan sehingga dapat dikatakan model permbelajaran BCCT pada anak kemandirian rendah tidak terlalau signifikan berpengaruh.

\section{Uji $T^{2}$ (t hoteling) untuk melihat perbedaan Hasil Anak yang mempunyai Kemandirian Tinggi antara Kelompok BCCT dan Non BCCT}

Hasil perhitungan Hipotesis di atas nilai $\mathrm{T}^{2}{ }_{\text {hitung }}(82.47)>\mathrm{C}^{2}$ (12.33) maka Ho ditolak, atau dapat disimpulkan bahwa Terdapat perbedaan Hasil Anak yang memiliki Kemandirian Tinggi antara kelompok BCCT dan Non BCCT. Untuk mengetahui masing-masing dimensi mana (Inisiatif, Tanggung 94
Jawab, Kontrol diri, Percaya Diri, Kemampuan Mengatasi Masalah dan Tidak Bergantung Orang Lain ) yang berbeda antara Kelompok BCCT dan Non BCCT maka digunakan Analisis lanjutan yaitu uji t independent.

Berdasarkan hasil penelitian lanjutan mengenai Kemandirian anak yang Tinggi antara BCCT dan NON BCCT, dapat diketahui bahwa ratarata inisiatif pada kelompok non BCCT adalah 1.69 selanjutnya untuk dimensi memiliki tanggung jawab sebesar 2.38, lalu pada dimensi kontrol diri sebesar 2.31, pada dimensi Percaya diri sebesar 2.13, pada dimensi Memiliki kemampuan mengatasi masalah sebesar 2.06 dan dimensi Tidak bergantung pada orang lain sebesar 1.88 .

Sedangkan pada kelompok BCCT diketahui bahwa rata-rata inisiatif sebesar 2.44, selanjutnya untuk dimensi memiliki tanggung jawab sebesar 2.38, lalu pada dimensi kontrol diri sebesar 2.31, pada dimensi Percaya diri sebesar 2.13, pada dimensi Memiliki kemampuan mengatasi masalah sebesar 2.06 dan dimensi Tidak 
bergantung pada orang lain sebesar 1.88 .

Terlihat bahwa pada kemandirian anak yang tinggi untuk kelompok Non BCCT dimensi paling tinggi berdasarkan rata-ratanya adalah pada Memiliki Tanggung Jawab, sedangkan pada kelompok BCCT adalah Dimensi Memiliki Kemampuan Mengatasi Masalah.

Berdasarkan hasil pengujian kesamaan rata-rata pada masingmasing dimensi, terlihat bahwa terdapat empat dimensi yang terdapat perbedaan pada kemandirian tinggi antara kelompok BCCT dan Non BCCT, yaitu pada Dimensi memiliki inisiatif, percaya diri, kemampuan mengatasi masalah, dan tidak bergantung orang lain, hal ini dikarenakan pada dimensi tersebut memiliki nilai $\mathrm{t}$ hitung $\geq \mathrm{t}$ tabel yaitu $\mathrm{t}$ hitung untuk memiliki inisiatif sebesar 2,127, selanjutnya pada percaya diri sebesar 2.091, lalu kemampuan mengatasi masalah sebesar 3,646 dan tidak bergantung orang sebesar 3.354 serta terlihat juga untuk probability sig. 2 tailed masing-masing lebih kecil dari taraf signifikansi 0.05 yang berarti Ho ditolak, dengan demikian dapat disimpulkan terdapat perbedaan yang signifikan pada kemandirian tinggi anak antara kelompok BCCT dan Non BCCT pada pada Dimensi memiliki inisiatif, percaya diri, kemampuan mengatasi masalah, dan tidak bergantung orang lain. Sedangkan pada dimensi kontrol diri dan memiliki tanggung jawab tidak demikian.

Pada pengujian hipotesis kelima pengujian dinyatakan terdapat perbedaan kemandirian antara kelompok BCCt dan Non BCCT. Hal tersebut mengartikan kelompok BCCT lebih tinggi kemandiriannya dibandingkan dengan Non BCCT. Berdasarkan deskriptif kemandirian tinggi pada anak, kelompok BCCT tetinggi pada bidang kemampuan mengatasi masalah dan pada Non BCCT memiliki tanggung jawab.

Dapat diartikan kemapuan mengatasi masalah pada kelompok BCCT dikarena anak terbiasa untuk belajar bereksplorasi sendiri dalam memecahkan masalah yang dihadapi saat bermain. Sedangkan 
perbandingan dimasing masing dimensi telihat bahwa tidak terdapat perbedaan antara dimensi memiliki tanggung jawab dan kontrol diri. Kedua dimensi tersebut dapat dikaitkan dengan pendidikan yang didapati dirumah atau di luar sekolah, dimana tanggung jawab dan kontrol diri dari anak dididik oleh orang tua dengan baik.

\section{Simpulan}

Berdasarkan hasil pengujian hipotesis dapat disimpulkan sebagai berikut:

1. Terdapat Perbedaan hasil anak dengan kreativitas rendah yang diajar menggunakan model pembelajaran Beyond Centers And Circles Time (BCCT) dan non BCCT.

2. Terdapat Perbedaan hasil anak dengan kreativitas Tinggi yang diajar menggunakan model pembelajaran Beyond Centers And Circles Time (BCCT) dan non BCCT. Dengan tidak adanya perbedaan yang signifikan pada dimensi original.

3. Terdapat pengaruh interaksi model pembelajaran Beyond
Centers And Circles Time

(BCCT) dan kemandirian terhadap kreativitas anak. Sedangkan pada kelompok non BCCT tidak terdapat perbedaan tingkat kemandirian pada kreativitas anak.

4. Terdapat Perbedaan hasil anak dengan kemandirian belajar rendah diajar menggunakan model pembelajaran Beyond Centers And Circles Time (BCCT) dan non BCCT. Dalam perbandingan masing-masing dimensi, dimensi inisitaif, kontrol diri, dan kemampuan mengatassi masalah tidak ada perbedaan yang signifikan.

5. Terdapat Perbedaan hasil anak dengan kemandirian belajar tinggi diajar menggunakan model pembelajaran Beyond Centers And Circles Time (BCCT) dan non BCCT. Dalam perbandingan masing-masing dimensi, dimensi memiliki tanggung jawab dan kontrol diri tidak ada perbedaan yang signifikan. 
Berdasarkan simpulan diatas penulis mememberikan beberapa rekomendasi antara lain:

a. Sebaiknya guru lebih mampu menstimulasi kreativitas dan kemandirian anak dengan memberikan kebebeasan yang luas untuk anak menjelajah berbagai pengalaman.

b. Pengoptimal kemandiran anak dapat diwujudkan dengan guru merencanakan pembelajaran yang tidak monoton dan menarik.

c. Diharapkan guru dapat mendengarkan keluh kesah masalah anak di dalam kelas. Sehingga anak merasa dimengerti dan penyelesaian masalah pada anak dapat terfokus.

d. Diharapkan guru dapat mengerti karakter masing-massing anak

\section{DAFTAR PUSTAKA}

Anoun. The Creative Center for Childhood Research and Training, Inc, BCCT. USA: Kaplan, 2005.

\section{Chaplin, C. P. Kamus Lengkap} Psikologi. Terjemahan Kartini Kartoni. Jakarta: PT. Raja Grafindo Persada. 1999. dalam mendidik tanpa membedakan latar belakang sosial.

e. Sarana yang disiapkan guru sebaiknya diperbanyak agar adanya kesesuaian antara media dan tema.

f. Kompetensi yang dimiliki guru tk sepatutnya dari bidang yang linera sehingga perkembangan pada anak dapat terjadi secara optimal.

g. Perlu adanya penelitian lanjutan tingkat kecemasan anak dengan model pembelajaran BCCT yang masuk disekolah dasar yang tidak menggunakan model pembelajaran BCCT serta tingkat kemampuan calistung pada kelompok tersebut yang dituntut untuk syarat masuk SD atau pembelajaran SD kelas 1.

Desmita. Psikologi Perkembangan Peserta Didik. Bandung: PT Remaja Rosda Karya. 2009.

Direktorat Pembinaan Pendidikan Anak Usia Dini. Pedoman Pendidikan Berkarakter Pada Anak Usia Dini. Jakarta: Direktorat Pembinaan 
Pendidikan Anak Usia Dini. 2012.

Seifert, K. L dan Hoffnung, R. J. Child and Adolescent Development. Boston: Houghton Mifflin Company. 1994.

Lilis Nuryani. Implementasi Model Pembelajaran BCCT di Kelompok B PAUD Ganesa Bandung. Bandung: UPI, 2012.

Munandar, Utami. Pengembangan kreativitas Anak Berbakat. Jakarta : Rineka Cipta. 2009. Peraturan Pemerintah No. 19 tahun 2005 tentang Standar Nasional Pendidikan, pasal 19 ayat 1.

Rachmawati, dan Kurniati E. Strategi Pengembangan Kreativitas pada Anak. Usia TK. Bandung: Kencana Prenada Media Group. 2010. Santrock, John W. Perkembangan Anak, Edisi ke-11 Jilid 1.Jakarta: Erlangga. 2007.

Sujiono, Yuliani Nurani. Konsep Dasar Pendidikan Anak Usia Dini. Jakarta: PT Indeks. 2009. 